\title{
4-hexylresorcinol exerts antitumor effects via suppression of calcium oscillation and its antitumor effects are inhibited by calcium channel blockers
}

\author{
SEONG-GON KIM $^{1}$ and JE-YONG CHOI ${ }^{2}$ \\ ${ }^{1}$ Department of Oral and Maxillofacial Surgery, College of Dentistry, Gangneung-Wonju National University, Gangneung; \\ ${ }^{2}$ Department of Biochemistry and Cell Biology, WCU Program, CMRI, Skeletal Diseases Genome Research Center, \\ School of Medicine, Kyungpook National University, Daegu, Republic of Korea
}

Received November 13, 2012; Accepted January 29, 2013

DOI: 10.3892/or.2013.2292

\begin{abstract}
The bacterial dormancy-inducing factor 4-hexylresorcinol (4-HR) has been shown to have synergistic antitumor effects when used in combination with cisplatin. In the present study, 4-HR was used as a single agent in the squamous carcinoma cell line SCC-9. The results demonstrated that 4-HR suppressed SCC-9 cell proliferation compared to primary cultured gingival fibroblasts. 4-HR dose-dependently induced SCC-9 cell apoptosis as determined by caspase-3 activity, Annexin $\mathrm{V}$ expression, as well as by scanning and transmission electron microscopy. 4-HR inhibited intracellular calcium oscillation in both SCC-9 cells and normal human dermal fibroblasts. 4-HR-induced apoptosis was partly reversed by calcium channel blockers. Of note, 4-HR reduced the tumor mass formed by SSC-9 cell implantation in BALB/ cAnNCrj-nu/nu mice and mass size reduction was also partly reversed by the concomitant application of calcium channel blockers. Collectively, our results suggest that 4-HR has strong antitumor effects by inhibiting calcium channel oscillation and inducing apoptosis.
\end{abstract}

\section{Introduction}

Resorcinol is a non-isoprenoid lipid found in a range of plant and bacterial species; they exert non-specific antioxidant and anti-mutagenic effects and regulate proliferation (1). Chemical analogs of these lipids have demonstrated anticancer effects in animal models of colon (2), lung (3) and pancreas tumor (4). 4-hexylresorcinol (4-HR) is also a chemical analog of these lipids (1).

Correspondence to: Professor Seong-Gon Kim, Department of Oral and Maxillofacial Surgery, College of Dentistry, Gangneung-Wonju National University, Jibyun-dong, Gangneung, Gangwon-do 210-702, Republic of Korea

E-mail:kimsg@gwnu.ac.kr

Key words: 4-hexylresorcinol, SCC-9 cell, apoptosis, therapeutic drug
In microorganisms, chemical analogs of 4-HR occur in dormant cysts $(5,6)$ and resting cyst-like cells $(7,8)$. Exogenous administration of these auto-regulatory factors and their analogs-alkyl resorcinol induces dormancy in bacteria (9); these compounds are similarly active in eukaryotic cells such as ras-transformed fibroblasts (10). Therefore, 4-HR may also inhibit the growth of tumor cells, altering their physiological state and activity. In a previous report, 4-HR showed a preventive effect in mononuclear cell leukemia, hepatocellular neoplasm, and circulatory system tumors $(11,12)$. Recently, combination therapy of 4-HR and cisplatin was shown to have synergistic effects in nasopharyngeal carcinoma (13). 4-HR inhibits the NF- $\kappa$ B pathway via the suppression of transglutaminase-2 (13,14). 4-HR also accelerates tumor differentiation by the suppression of E2F2 and E2F3 (15).

The aim of the present study was to determine the potential antitumor effects of 4-HR as a single agent on oral squamous cell carcinoma (OSCC). Additionally, the change of intracellular calcium following 4-HR application and drug interaction with calcium channel blockers were demonstrated. We used in vitro SCC-9 cell culture and in vivo xenograft model systems and assessed cell viability, intracellular calcium tracking and apoptosis.

\section{Materials and methods}

Cell cultures and MTT assay. SCC-9 was grown to confluence in Ham's F12/Dulbecco's modified Eagle's medium (Gibco BRL, Gaithersburg, MD, USA) containing $1 \%$ penicillin/ streptomycin, fibroblast growth factor-2 $(100 \mu \mathrm{g} / \mathrm{ml})$ and $10 \%$ fetal calf serum (FCS). Primary cultured human gingival fibroblasts (PHGF) were used as controls. 4-HR (Sigma, St. Louis, MO, USA) was added to confluent cells to final concentrations of 1 , 5 or $10 \mu \mathrm{g} / \mathrm{ml}$.

Cell viability quantification at $48 \mathrm{~h}$ after 4-HR application was assessed by tetrazolium salt 3-(4,5-dimethylthiazole-2-yl)2,5-diphenyltetrazolium bromide (MTT) assay as previously described (16). Briefly, cells were incubated with MTT solution (Cell Proliferation kit I; Roche Molecular Biochemicals, Mannheim, Germany) in 6-well plates for $4 \mathrm{~h}$ at room temperature. Formazan crystals were solubilized overnight, and the 
product was estimated by measuring absorbance at $590 \mathrm{~nm}$ with a Victor Multilabel counter (Perkin-Elmer Wallac GmbH, Freiburg, Germany).

Apoptosis and caspase-3/7 assays. Apoptosis was determined with the Annexin V-FITC Apoptosis Detection kit I (BD Biosciences, San Jose, CA, USA) following a 2-h incubation with 4-HR. The caspase assay was performed with a commercial kit (Caspase-Glo ${ }^{\circledR}$ 3/7 assay, Promega, Madison, WI, USA) at 30 min after 4-HR was added. Cell culture in medium lacking 4-HR was used as negative control.

Calcium tracking with confocal microscopy and calcium channel study. To monitor calcium, SCC-9 cells were treated with Fluo-4 NW calcium assay kit (Molecular Probes, Eugene, OR, USA), and then visualized using a laser scanning confocal microscope (Leica Microsystems Heidelberg GmbH, Mannheim, Germany) as previously described (17).

Calcium channel antagonists (blockers) were used to confirm the role of calcium in 4-HR-mediated proliferation and apoptosis. SCC-9 cells were exposed to Norvasc $(0.1,0.5$ or $1 \mu \mathrm{g} / \mathrm{ml}$; Pfizer Korea, Seoul, Korea), and 4-HR (10 $\mu \mathrm{g} / \mathrm{ml})$ was added 2 h later; control cells did not receive Norvasc. The MTT cell proliferation assay was performed $24 \mathrm{~h}$ after $4-\mathrm{HR}$ treatment. Subsequently, SCC-9 cells were treated with calcium channel antagonists (Norvasc or diltiazem; $1 \mu \mathrm{g} / \mathrm{ml}$ ) for $2 \mathrm{~h}$ before exposure to 4-HR. Diltiazem was obtained from Sigma. The caspase-3/7 assay was performed $30 \mathrm{~min}$ after 4-HR application.

Scanning and transmission electron microscopy. Following a 24-h incubation with $10 \mu \mathrm{g} / \mathrm{ml}$ 4-HR, SCC-9 cell suspension was applied to copper grids and dried in a vacuum to prepare for scanning electron microscopy (SEM). SCC-9 cells treated with $10 \mu \mathrm{g} / \mathrm{ml}$ cisplatin for $24 \mathrm{~h}$ were included as a positive control. Prior to transmission electron microscopy (TEM) analysis, cells were harvested by centrifugation at $300 \mathrm{x}$ g for $10 \mathrm{~min}$, and then dehydrated and fixed (18). Specimens were polymerized in Spurr (Epon 812) resin, cut on an ultratome (Leica, Uppsala, Sweden), stained with lead citrate, and mounted on copper grids. SEM and TEM were performed using a JEOL microscope (Tokyo, Japan) operating at accelerating voltage $15.0 \mathrm{kv}$ and magnification $\times 7000$.

Tumor xenograft model. Male nude mice (BALB/ cAnNCrj$\mathrm{nu} / \mathrm{nu}$ ) were purchased from Charles River Japan Inc. (Shin-Yokohama, Japan). Seventeen mice were subcutaneously injected with SCC-9 cells $\left(2.5 \times 10^{6}\right)$; all subsequently developed tumors. Commencing on the following day, two experimental groups (each group, $n=6$ ) received daily intraperitoneal injections of $4-\mathrm{HR}(10 \mathrm{mg} / \mathrm{kg}$ of body weight) for 16 days, while the control group $(n=5)$ received daily injections of the vehicle (normal saline). Another group of mice received daily intraperitoneal injections of $4-\mathrm{HR}(10 \mathrm{mg} / \mathrm{kg}$ of body weight) plus diltiazem ( $20 \mathrm{mg} / \mathrm{kg}$ of body weight) for 16 days $(19,20)$. Tumors were measured in two dimensions with calipers every 2 or 3 days, and tumor volumes were calculated with the following formula: volume $=a \times b^{2} / 2$, where $a$ is the tumor measurement at its widest point and $\mathrm{b}$ is the measurement perpendicular to a. Tumor weight was determined at the time of sacrifice.
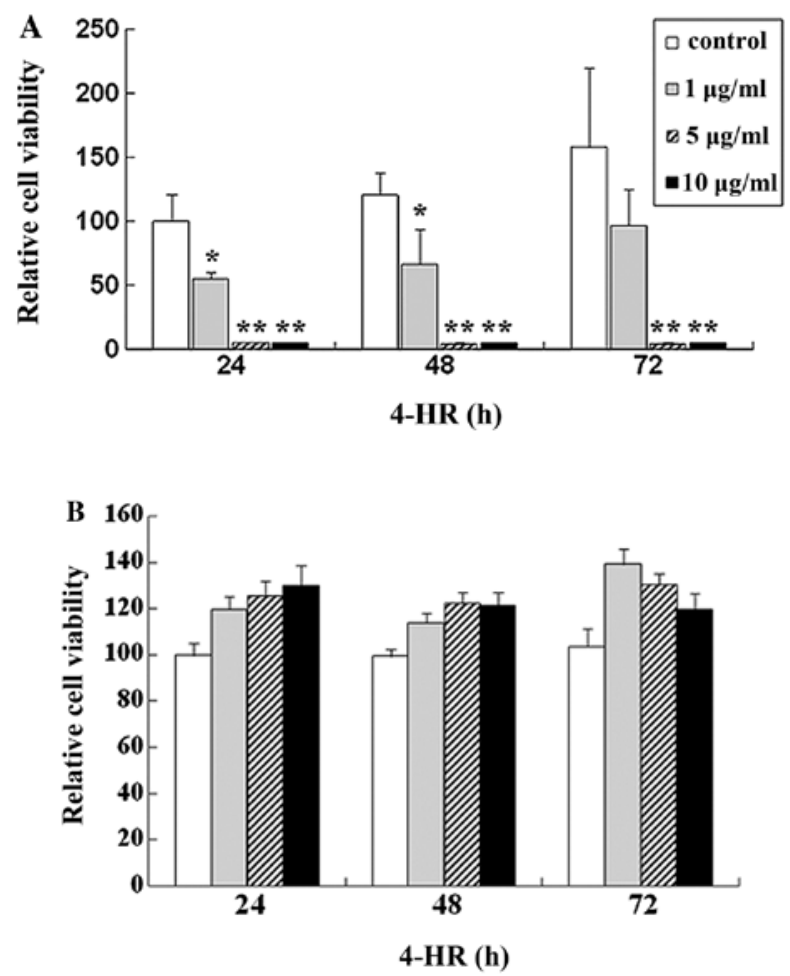

Figure 1. Effect of 4-hexylresorcinol (4-HR) on SCC-9 cell proliferation. Cells were cultured for two days after seeding and then treated with various concentrations of 4-HR. Cell proliferation was determined by MTT assay. (A) SCC-9 cells and (B) primary cultured human gingival fibroblasts demonstrated markedly different proliferation responses to 4-HR. Relative activity was based on 24-h control group. Data are expressed as the means $\pm \operatorname{SD}$ ( $n=6$; $\left.{ }^{*} \mathrm{P}<0.05,{ }^{* *} \mathrm{P}<0.01\right)$.

Statistical analysis. The difference between the untreated control and the drug-treated group in each experiment was compared by independent sample t-test. Inhibitory concentration $50\left(\mathrm{IC}_{50}\right)$ was calculated at $48 \mathrm{~h}$ after $4-\mathrm{HR}$ administration by linear regression analysis. $\mathrm{P}<0.05$ was considered to indicate a statistically significant difference.

\section{Results}

4-HR inhibits SCC-9 cell proliferation. Initially, we determined the effect of 4-HR on SCC-9 cell viability. Relative cell viability after treatment with 1,5 and $10 \mu \mathrm{g} / \mathrm{ml} 4$-HR was 55.0 , 5.2 and $4.7 \%$, respectively, compared with control $(\mathrm{P}=0.043$, 0.007 and 0.007) (Fig. 1A). By contrast, 4-HR exerted only a slight effect on PHGF (Fig. 1B). $\mathrm{IC}_{50}$ was $2.94 \mu \mathrm{g} / \mathrm{ml}$ for SCC-9. However, $\mathrm{IC}_{50}$ of PHGF was $49.30 \mu \mathrm{g} / \mathrm{ml}$.

4-HR induces apoptosis of SCC-9 cells. Subsequently, we determined whether 4-HR could induce apoptosis. Following treatment with 4-HR $(10 \mu \mathrm{g} / \mathrm{ml})$, SCC-9 cells were considerably smaller and rounder compared with control cells (data not shown), suggesting apoptosis. SEM and TEM examinations revealed: i) the appearance of apoptotic bodies around cells following 4-HR treatment (10 $\mu \mathrm{g} / \mathrm{ml})$, which was similar to cells treated with cisplatin, and ii) cleaved or fragmented nuclei with finger-like projections, which is a typical feature of apoptosis (Fig. 2A). By contrast, control cells exhibited smooth surfaces and intact intra-cytoplasmic structures and nuclei. Following 
A
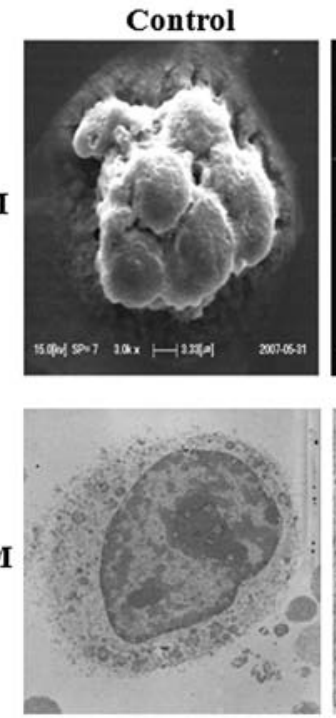

4-HR
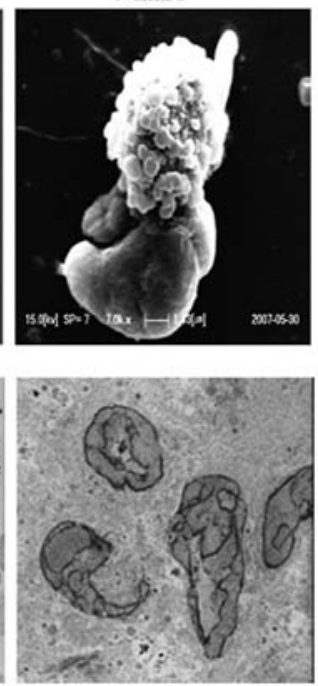
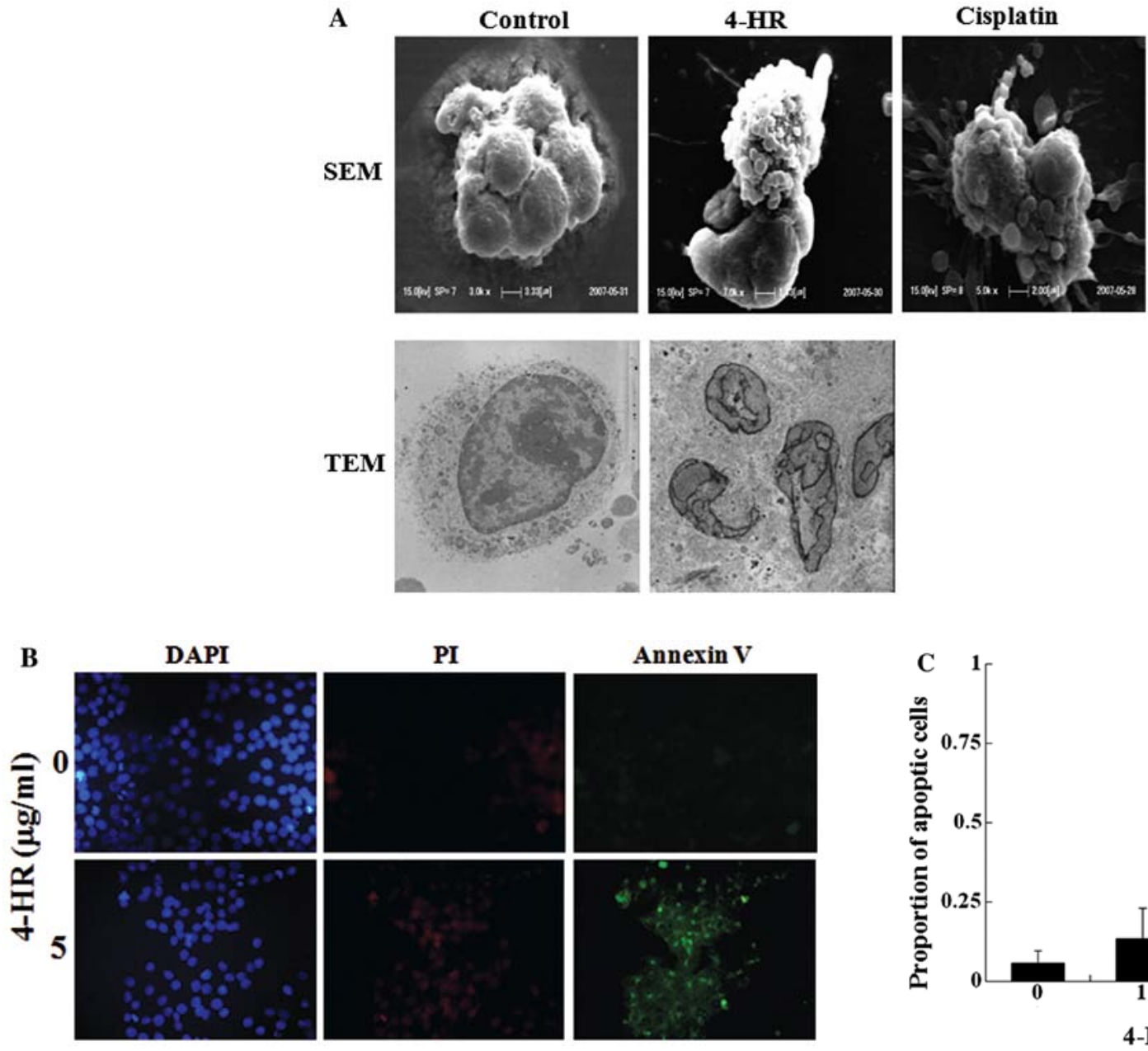

PI
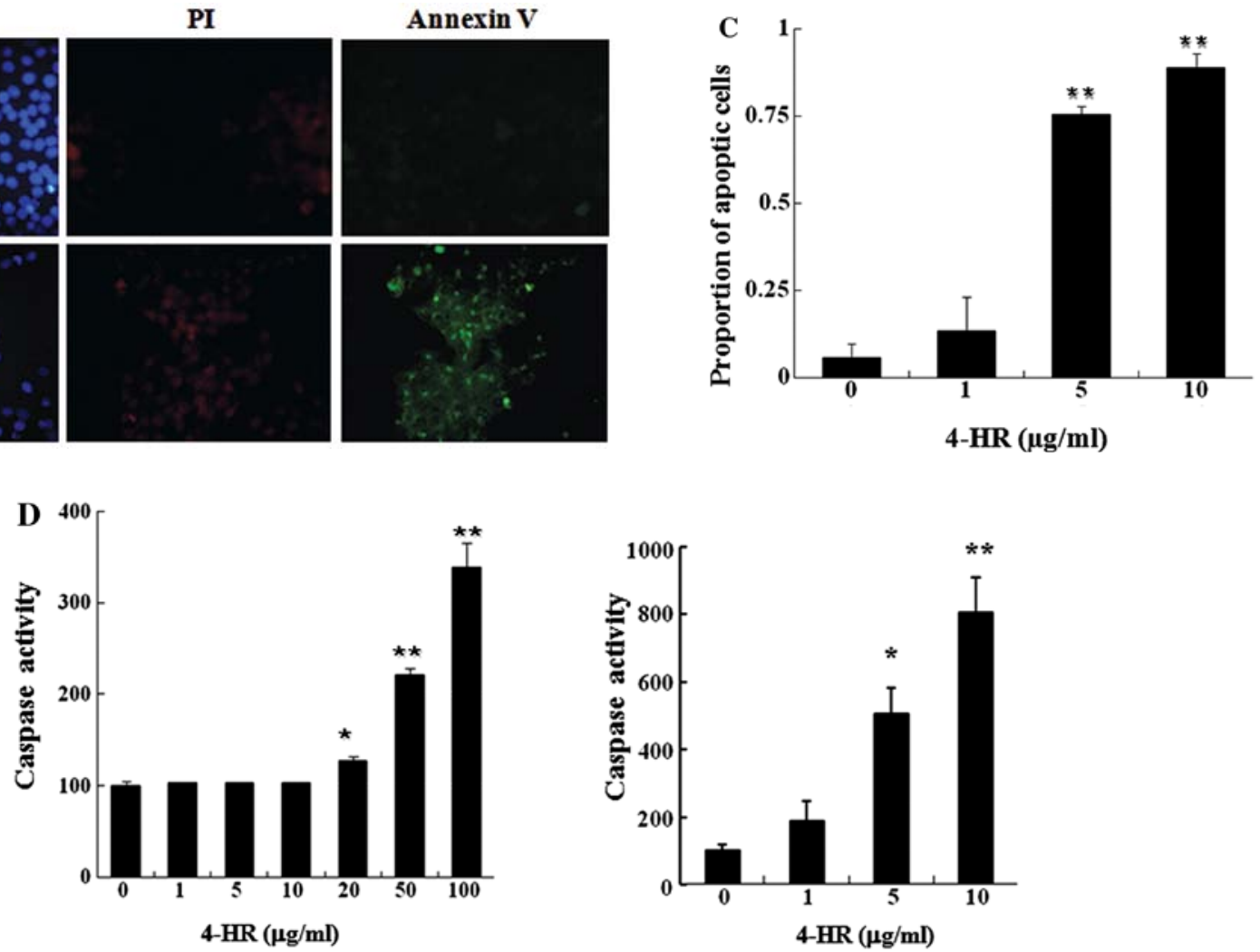

Figure 2. 4-hexylresorcinol (4-HR)-induced morphological and biochemical changes in SCC-9 cells. SCC-9 cells were treated with or without 4-HR (10 $\mu \mathrm{g} / \mathrm{ml})$ for $24 \mathrm{~h}$. Cell morphology was visualized by scanning electron microscopy (SEM) and transmission electron microscopy (TEM). (A) Round shape, outward lobulation, and nucleus fragmentation were observed in 4-HR-treated cells (TEM original magnification, x3000). (B) SCC-9 cells treated with 4-HR (5 $\mu \mathrm{g} / \mathrm{ml})$ were positive for staining with Annexin V (original magnification, x100). Propidium iodide (PI) indicates nucleus staining. (C) The proportion of apoptotic cells was significantly increased in 5 and $10 \mu \mathrm{g} / \mathrm{ml} 4-\mathrm{HR}$ compared to the untreated control ( ${ }^{* *} \mathrm{P}<0.01$ ). (D) $4-\mathrm{HR}$ had a slight effect on caspase-3/7 activity in primary culture human gingival fibroblasts $\leq 10 \mu \mathrm{g} / \mathrm{ml}$ (left panel), but exerted a strong dose-dependent effect in SCC-9 cells (right panel) ("P<0.05, $\left.{ }^{* *} \mathrm{P}<0.01\right)$.

treatment with 4-HR $(5 \mu \mathrm{g} / \mathrm{ml})$, SCC-9 cells became stainable with Annexin V (Fig. 2B), most likely due to membrane changes, a primary event in apoptosis. The proportion of apoptotic cells was significantly increased in 5 and $10 \mu \mathrm{g} / \mathrm{ml} 4-\mathrm{HR}$ compared to the untreated control (Fig. 2C). To confirm 4-HR-mediated apoptosis, caspase-3/7 activity was determined. Caspase-3/7 activity was dose-dependently increased by 4-HR in SCC-9 cells (Fig. 2D, right panel), while its activity was marginally increased in PHGF from $20 \mu \mathrm{g} / \mathrm{ml}$ of 4-HR (Fig. 2D, left panel). These results indicate that 4-HR selectively induces apoptosis of SCC-9 cells at lower concentrations than PHGF.

Differential effects of 4-HR on intracellular calcium signaling in SCC-9 cells. Calcium is known to play role in cell proliferation, differentiation and apoptosis; therefore, we assessed calcium uptake in SCC-9 cells. As shown in Fig. 3A, intra- 

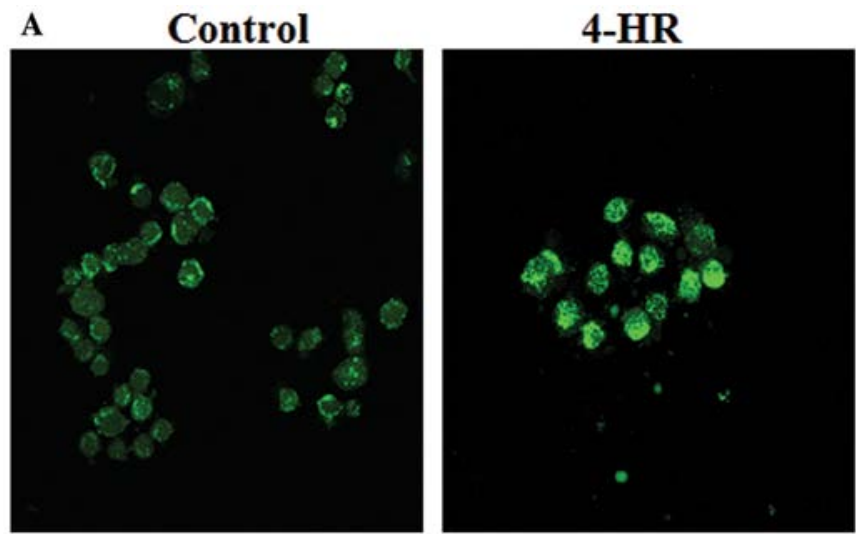

B
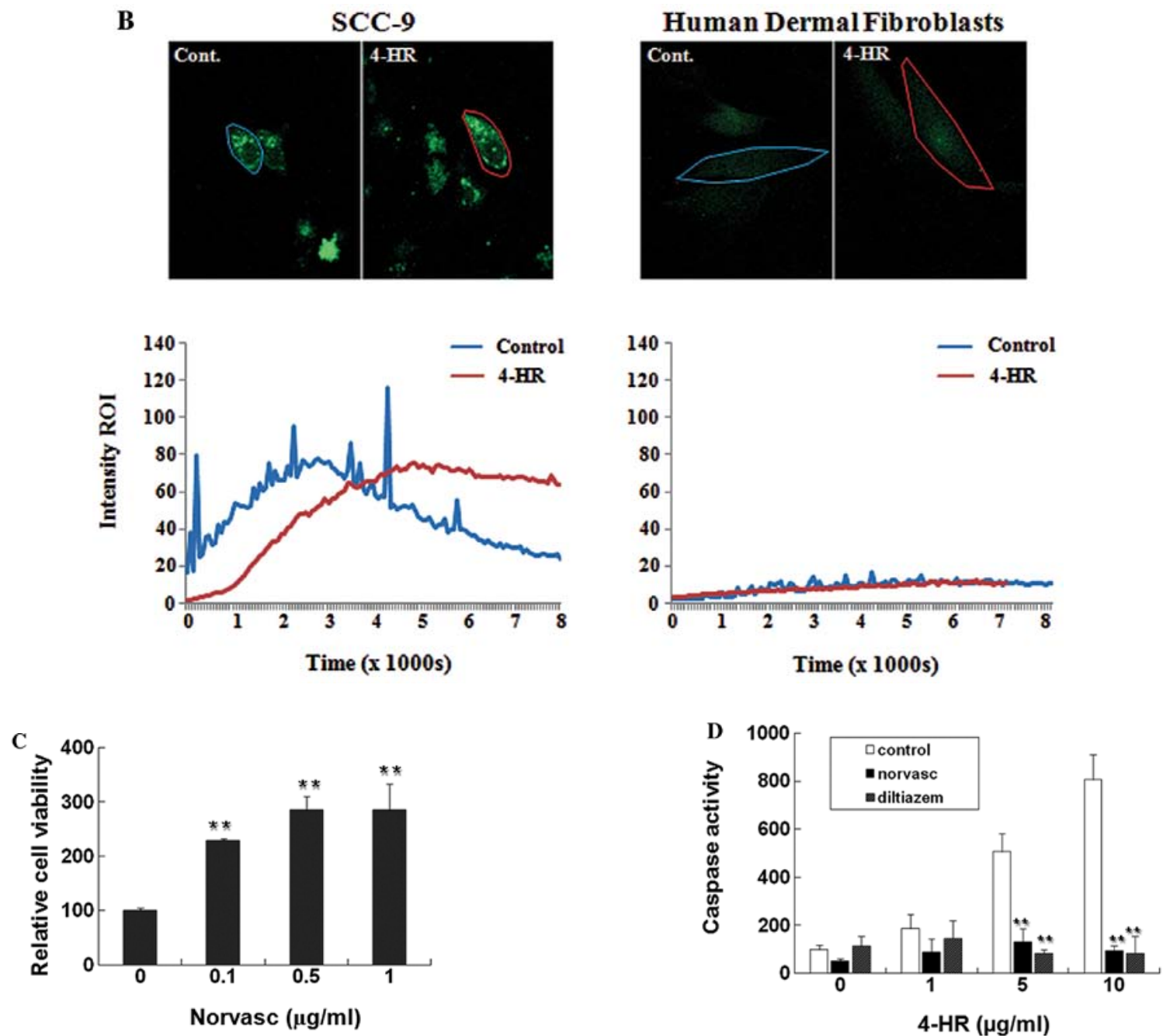

Figure 3. Essential role of intracellular calcium for 4-hexylresorcinol (4-HR)-mediated biological effects in SCC-9 cells. (A) Control and 4-HR-treated SCC-9 cells visualized by confocal microscopy after staining with calcium-sensitive Fluo-4 AM. Intracellular calcium content increased 10 min after addition of 4-HR (10 $\mu \mathrm{g} / \mathrm{ml})$ (original magnification, x200). (B) Differential effects of 4-HR on intracellular calcium kinetics between SCC-9 cells (left panel) and normal dermal fibroblasts (right panel). Quantification of calcium signals by image analysis and immunofluorescence staining (inserts). (C) The 4-HR-mediated antiproliferative effect was attenuated by a calcium channel blocker. Cells were pretreated with Norvasc prior to $24-\mathrm{h}$ treatment with $4-\mathrm{HR}(10 \mu \mathrm{g} / \mathrm{ml})$, and then assessed by MTT assay ( $\left.{ }^{* *} \mathrm{P}<0.01\right)$. (D) The 4-HR-mediated apoptotic effect was abrogated by calcium channel blockers. Cells were pretreated with calcium channel blockers prior to $30-\mathrm{min}$ treatment with $4-\mathrm{HR}(1 \mu \mathrm{g} / \mathrm{ml})\left({ }^{* *} \mathrm{P}<0.01\right)$.

cellular calcium was significantly increased in SCC-9 cells after 4-HR treatment $(10 \mu \mathrm{g} / \mathrm{ml})$ compared with control cells. Furthermore, increased intracellular calcium was observed specifically in SCC-9 cells, but not in normal dermal fibroblasts (Fig. 3B). In SCC-9 cells, 4-HR treatment delayed the decrease in intracellular calcium after peak concentration; however, in normal dermal fibroblasts, peak calcium levels were much lower, and 4-HR did not affect the kinetics of the calcium response. Notably, 4-HR suppressed calcium oscillation in both SCC-9 cells and normal dermal fibroblasts (Fig. 3). 

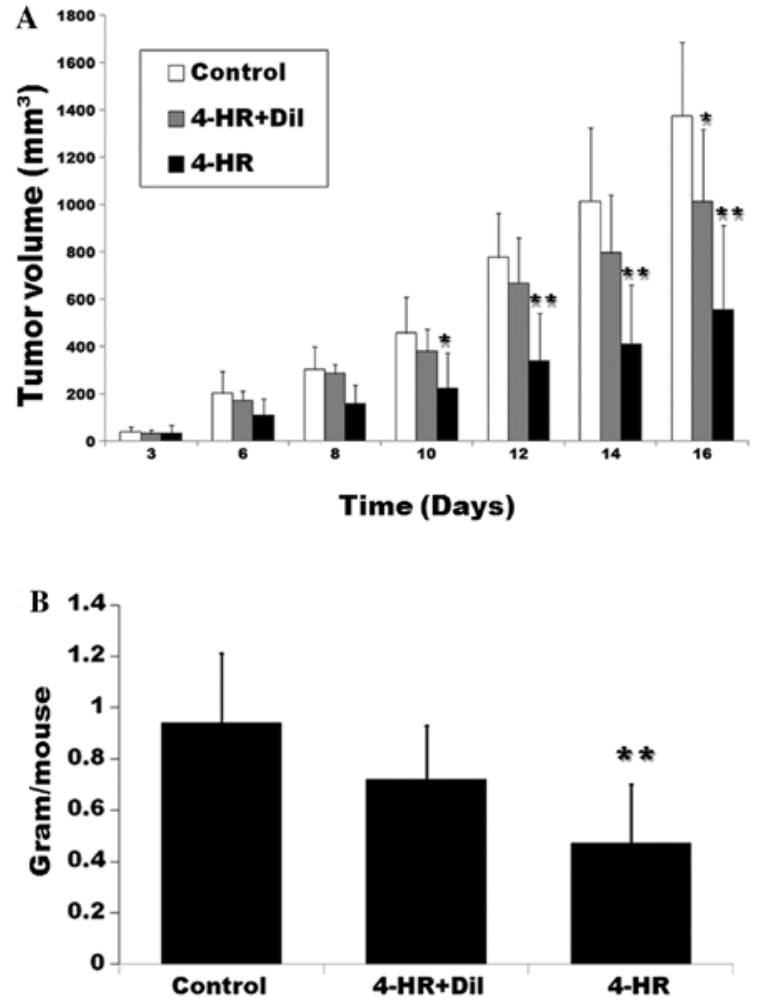

Figure 4. 4-hexylresorcinol (4-HR) inhibits tumor formation in SCC-9 cells injected into a nude mice xenograft model. (A) Mice were sacrificed at Day 16. Three representative tumor masses are shown among samples in each group ( $\mathrm{n}=5$ or 6$)$. Enucleated masses were injected with saline (control), $10 \mathrm{mg} / \mathrm{kg} 4-\mathrm{HR}+20 \mathrm{mg} / \mathrm{kg}$ diltiazem (4-HR+Dil), or $10 \mathrm{mg} / \mathrm{kg}$ 4-HR (4-HR). The graph compares mean tumor size throughout the experiment $\left({ }^{*} \mathrm{P}<0.05\right.$, ${ }^{* *} \mathrm{P}<0.01$ ). (B) Mass weight was measured at the time of necropsy. Average mass weight per mouse of the saline group was compared to the 4-HR only or the 4-HR + Dil group $\left({ }^{*} \mathrm{P}<0.05,{ }^{* *} \mathrm{P}<0.01\right)$.

Calcium blockers were used to confirm the essential role of calcium uptake. As shown in Fig. 3C, the 4-HR anti-proliferative effect was inhibited by Norvasc $(0.1-1 \mu \mathrm{g} / \mathrm{ml} ; \mathrm{P}<0.001)$; cellular proliferation was increased $\sim 3$-fold compared with the 4-HR control. Calcium channel blockers Norvasc and diltiazem also blocked 4-HR-mediated caspase-3/7 activity in SCC-9 cells ( $\mathrm{P}<0.001$ in 5 and $10 \mu \mathrm{g} / \mathrm{ml}$ of $4-\mathrm{HR}$; Fig. 3D). These results confirm that 4-HR-mediated effects are due, in part, to increased intracellular calcium.

4-HR reduces tumor formation in a xenograft in vivo model. Next, we tested 4-HR antitumor effects in the xenograft model. SCC-9 cells were injected subcutaneously into nude mice. In mice receiving daily $4-\mathrm{HR}$ treatment $(10 \mathrm{mg} / \mathrm{kg})$ for 16 days, tumor mass was markedly smaller compared with the control group ( $\mathrm{P}=0.003$; Fig. 4A). In mice receiving concomitant application of 4-HR and diltiazem, tumor mass was significantly larger compared with the 4-HR group $(\mathrm{P}=0.038)$. There was no statistically significant difference between the control and the $4-\mathrm{HR}+$ diltiazem group $(\mathrm{P}>0.05)$. At the time of necropsy, the average mass weight was $0.94 \pm 0.27 \mathrm{~g} /$ mouse in the control group (Fig. 4B), $0.72 \pm 0.21 \mathrm{~g} /$ mouse in the $4-\mathrm{HR}+$ diltiazem group and $0.47 \pm 0.23 \mathrm{~g} / \mathrm{mouse}$ in the $4-\mathrm{HR}$ group. When compared to the control, the 4-HR group was statistically significantly different $(\mathrm{P}=0.007)$. Taken together, these results indicate that 4-HR inhibits tumor cell proliferation in mouse tumor xenografts and concomitant application of calcium channel blocker partly reverses the antitumor effect of 4-HR.

\section{Discussion}

In the present study, we demonstrated that 4-HR strongly inhibited SCC-9 cell proliferation compared with normal fibroblasts, and induced apoptosis. Furthermore, these in vitro effects were reproducible in xenografts after SCC-9 cell implantation in nude mice. The antitumor effect of 4-HR was partly reversed by the application of calcium channel blockers both in vitro and in vivo.

4-HR also induced the apoptosis of PHGF, although at a significantly higher concentration ( $>20 \mu \mathrm{g} / \mathrm{ml}$; Fig. 2D), which is in accordance with previous results (21). 4-HR targets transformed cells via an unknown mechanism. Although this study focused on SCC-9 cells, we also observed the inhibitory action of 4-HR on gastric adenocarcinoma, breast cancer, lung cancer, and hepatoma cells (data not shown), suggesting that 4-HR may be applicable to other types of cancer. Selective tumor cell apoptosis is one objective in developing anticancer drugs. In the present study, we demonstrated that 4-HR stimulated apoptosis of SCC-9 cells, but not of PHGF.

4-HR increases epithelial cell differentiation in SCC-9 cells (15). The calcium is important in the epithelial cell differentiation (22). 4-HR inhibits TG-2 activity (14) and the activity of TG-2 is also calcium dependent (23). Therefore, the molecular mechanisms of the observed 4-HR-mediated effects may be partly dependent on calcium. Calcium uptake is due, in part, to upregulation of voltage-dependent calcium channels; calcium channel blockers attenuated 4-HR-mediated cellular effects include protein kinase $\mathrm{C}-\alpha$, which plays an important role in calcium-induced keratinocyte differentiation (22). The effects of 4-HR on cancer cell proliferation and differentiation may also be due to non-specific interactions with other proteins (24), changes in membrane permeability (25), and/ or antioxidant and, thus, anti-mutagenic activities (26). A possible mechanism concerning the different uptake of calcium ion by 4-HR in OSCC cells and fibroblasts might be related to the glutamate receptor. The gene expression of ionotropic glutamate receptors was decreased by 4-HR application (data not shown). Glutamate receptor is related to calcium oscillation $(27,28)$ and OSCC highly expresses glutamate receptor (29). However, the glutamate receptor-related hypothesis remains to be confirmed in further experimental studies.

The effects of 4-HR on apoptosis are dose-dependent; relatively high doses $(5-10 \mu \mathrm{g} / \mathrm{ml})$ of $4-\mathrm{HR}$ caused the rupture of cellular membranes. This is similar to the effect of conventional anticancer drugs, which are typically toxic and induce apoptosis in cancer cells (30). However, the anti-proliferative effect of 4-HR at a low concentration $(1 \mu \mathrm{g} / \mathrm{ml})$ was not accompanied by cytotoxicity or apoptosis. In the previous 16 days, toxicology and carcinogenesis studies demonstrated that oral doses of 4-HR up to $500 \mathrm{mg} / \mathrm{kg}$ did not affect the survival of experimental animals (12). In the present study, the effective dose of 4-HR was significantly lower (10 $\mathrm{mg} / \mathrm{kg}$ body weight) than a previous animal study (12). However, prolonged use of 4-HR causes nephropathy and osteosclerosis in humans (31) as well as in animals (11). This may be due to increased intracellular calcium concentrations and the inhibition of the NF- $\mathrm{B}$ pathway (13). 
Collectively, our results suggest that 4-HR has strong antitumor effects by inhibiting calcium channel oscillation and inducing apoptosis. The antitumor effects of 4-HR were partly reversed by the application of calcium channel blockers.

\section{Acknowledgements}

The authors thank Dr Janet S. Stein for the critical reading of the manuscript. This study was supported by a grant from the Next-Generation BioGreen21 Program (Center for Nutraceutical and Pharmaceutical Materials no. PJ009013), Rural Development Administration, Republic of Korea.

\section{References}

1. Kozubek A and Tyman JHP: Resorcinolic lipids, the natural nonisoprenoid phenolic amphiphiles and their biological activity. Chem Rev 99: 1-25, 1999.

2. Mutoh M, Takahashi M, Fukuda K, et al: Suppression of cyclooxygenase-2 promoter-dependent transcription activity in colon cancer cells by chemopreventive agents with a resorcin-type structure. Carcinogenesis 21: 959-963, 2000.

3. Hasegawa R, Furukawa F, Toyoda K, et al: Inhibitory effect of antioxidants on $\mathrm{N}$-bis(2-hydroxypropyl)nitrosamine-induced lung carcinogenesis in rats. Jpn J Cancer Res 81: 871-877, 1990.

4. Maruyama H, Amamura T, Nakae D, et al: Effects of catechol and its analogs on pancreatic carcinogenesis initiated by $N$-nitrosobis(2-oxopropyl)amine in Syrian hamsters. Carcinogenesis 12: 1331-1334, 1991.

5. Chin D, Boyle GM, Porceddu S, Theile DR, Parsons PG and Coman WB: Head and neck cancer: past, present and future. Expert Rev Anticancer Ther 6: 1111-1118, 2006.

6. Braakhuis BJ, Tabor MP, Kummer JA, Leemans CR and Brakenhoff RH: A genetic explanation of Slaughter's concept of field cancerization: evidence and clinical implications. Cancer Res 63: 1727-1730, 2003.

7. Reusch RN and Sadoff HL: 5-n-Alkylresorcinols from encysting Azotobacter vinelandii: isolation and characterization. J Bacteriol 139: 448-453, 1979.

8. Reusch RN and Sadoff HL: Novel lipid components of the Azotobacter vinelandii cyst membrane. Nature 302: 268-270, 1983.

9. Osipov GA, El'-Registan GI, Svetlichnyi VA, Kozlova AN and Duda VV: Chemical nature of the autoregulating factor $\mathrm{d} 1$ in Pseudomonas carboxydoflava. Mikrobiologiia 54: 186-190, 1985 (In Russian).

10. El'-Registan GI, Tsyshnatii GV, Duzha MV, Pronin SV and Mitiushina LL: Regulation of Pseudomonas carboxydoflava growth and development by specific endogenous factors. Mikrobiologiia 49: 561-565, 1980 (In Russian).

11. Chhabra RS, Huff JE, Haseman J, Hall A, Baskin G and Cowan M: Inhibition of some spontaneous tumors by 4-hexylresorcinol in F344/N rats and B6C3F1 mice. Fundam Appl Toxicol 11: 685-690, 1988

12. National Toxicology Program: NTP toxicology and carcinogenesis studies of 4-hexylresorcinol (CAS No. 136-77-6) in F344/N rats and $\mathrm{B} 6 \mathrm{C} 3 \mathrm{~F}_{1}$ mice (Gavage Studies). Natl Toxicol Program Tech Rep Ser 330: 1-166, 1988.

13. Kim SG, Lee SW, Park YW, Jeong JH and Choi JY: 4-hexylresorcinol inhibits NF- $\kappa \mathrm{B}$ phosphorylation and has a synergistic effect with cisplatin in KB cells. Oncol Rep 26: 1527-1532, 2011.
14. Kim SG, Jeong JH, Park YW, et al: 4-hexylresorcinol inhibits transglutaminase-2 activity and has synergistic effects along with cisplatin in KB cells. Oncol Rep 25: 1597-1602, 2011.

15. Kim SG, Kim AS, Jeong JH, Choi JY and Kweon H: 4-hexylresorcinol stimulates the differentiation of SCC-9 cells through the suppression of E2F2, E2F3 and Sp3 expression and the promotion of Sp1 expression. Oncol Rep 28: 677-681, 2012.

16. Grossi F and Aita M: Bevacizumab and non-small-cell lung cancer: starving the enemy to survive. Expert Opin Biol Ther 7: 1107-1119, 2007.

17. Trollinger DR, Cascio WE and Lemasters JJ: Selective loading of Rhod 2 into mitochondria shows mitochondrial $\mathrm{Ca}^{2+}$ transients during the contractile cycle in adult rabbit cardiac myocytes. Biochem Biophy Res Comm 236: 738-742, 1997.

18. Guejes L, Zurgil N, Deutsch M, Gilburd B and Shoenfeld Y: The influence of different cultivating conditions on polymorphonuclear leukocyte apoptotic processes in vitro, I: the morphological characteristics of PMN spontaneous apoptosis. Ultrastruct Pathol 27: 23-32, 2003.

19. El-Azab MF and Moustafa YM: Influence of calcium channel blockers on anticonvulsant and antinociceptive activities of valproic acid in pentylenetetrazole-kindled mice. Pharmacol Rep 64: 305-314, 2012.

20. Luszczki JJ, Trojnar MK, Trojnar MP, et al: Effects of three calcium channel antagonists (amlodipine, diltiazem, and verapamil) on the protective action of lamotrigine in the mouse maximal electroshock-induced seizure model. Pharmacol Rep 59: 672-682, 2007.

21. Il'inskaya ON, Kolpakov AI, Mulyukin AL, Dreyer F and El'-Registan GI: Effects of membrane-active microbial autoregulators on the growth of cultured ras-transformed fibroblasts. Appl Biochem Microbiol 36: 473-477, 2000.

22. Yang LC, Ng DC and Bikle DD: Role of protein kinase C $\alpha$ in calcium induced keratinocyte differentiation: defective regulation in squamous cell carcinoma. J Cell Physiol 195: 249-259, 2003.

23. Jung HJ, Chen Z, Wang M, et al: Calcium blockers decrease the bortezomib resistance in mantle cell lymphoma via manipulation of tissue transglutaminase activities. Blood 119: 2568-2578, 2012.

24. Rimando AM, Dayan FE and Streibig JC: PSII inhibitory activity of resorcinolic lipids from Sorghum bicolor. J Nat Prod 66: 42-45, 2003.

25. Kozubek A and Demel RA: Permeability changes of erythrocytes and liposomes by 5 -(n-alk(en)yl) resorcinols from rye. Biochim Biophys Acta 603: 220-227, 1980.

26. Hladyszowski K, Zubik L and Kozubek A: Quantum mechanical and experimental oxidation studies of pentadecylresorcinol, olivetol, orcinol and resorcinol. Free Radical Res 28: 359-368, 1998.

27. Bezzi P, Carmignoto G, Pasti L, et al: Prostaglandins stimulate calcium-dependent glutamate release in astrocytes. Nature 391: 281-285, 1998

28. Parri HR, Gould TM and Crunelli V: Spontaneous astrocytic $\mathrm{Ca}^{2+}$ oscillations in situ drive NMDAR-mediated neuronal excitation. Nat Neurosci 4: 803-812, 2001.

29. Choi SW, Park SY, Hong SP, Pai H, Choi JY and Kim SG: The expression of NMDA receptor 1 is associated with clinicopathological parameters and prognosis in the oral squamous cell carcinoma. J Oral Pathol Med 33: 533-537, 2004.

30. Schwerdt G, Freudinger R, Schuster C, Weber F, Thews O and Gekle M: Cisplatin-induced apoptosis is enhanced by hypoxia and by inhibition of mitochondria in renal collecting duct cells. Toxicol Sci 85: 735-742, 2005.

31. Robinson HM Jr: Effective antifungal drugs and indications for their use. Med Clin North Am 51: 1181-1188, 1967. 